\title{
Influence of Panicum maximum Replacement of Clover Hay on the Performance of Growing Rabbits
}

\author{
Amira Mahmoud Refaie*, Walaa Attia Salama, Ahmed Elsayed Shams El-deen, Malak Mansour Beshara, Fouad \\ Said Khalil, and Ahmed Moner Alazab
}

Animal Production Research Institute, Agriculture Research Center, Dokki, Giza-12618, Egypt

*Corresponding author's Email: amera.refay@arc.sci.eg, (DORCID: 0000-0001-9283-3007

\begin{abstract}
Two experiments were performed to evaluate Panicum maximum (Pm) and its effect on rabbits' growth performance. In the first experiment, six adult V-line male rabbits were used to determine the digestible energy in Pm by continuously feeding these 120 gram (g) Pm and 120 g clover hay for 3 days, and then the digestible energy was recorded $1959 \mathrm{kcal} / \mathrm{kg}$. In second experiment, a total of 64 rabbits of V-line, 6 weeks old with average weight of $702 \mathrm{~g}$, were divided into 4 groups, each in 4 replicates (4 rabbits/replicate), the first fed basic diet; control (T1), the 3 groups fed on the diet contained Pm to replace clover hay as a percentage of $15 \%, 30 \%$ and $45 \%$, which corresponds to $4.5 \%, 9 \%$ and $13.5 \%$ of the total diet; which represent T2, T3, and T4, respectively. Rabbits were fed ad libitum with pellet feed until the end of growth attempt (14 weeks). The results indicated that the proximate analysis of $\mathrm{Pm}$ was $11.65 \%$ crude protein, $2.67 \%$ crude fat, and $30.66 \%$ crude fiber. Rabbits in T4 group significantly had the best final weight, daily weight gain, and Feed Conversion Ratio FCR. All groups had high crude protein digestibility except the group fed T3 diet. The total number of cecum bacterial count was improved in all tested groups. In conclusion, feeding growing rabbits with Pm up to $45 \%$ instead of clover hay achieved higher growth performance and lower cecum coliform bacteria.
\end{abstract}

Key words: Cecum bacteria, Growth performance, Panicum maximum, Rabbits.

\section{INTRODUCTION}

Clover hay is a conventional feed ingredient in rabbit nutrition in Egypt. However, the price is rising sharply, so it is necessary to find alternatives which are included in diets to produce balanced pellet feeds by using local raw materials that are available at a low price. Thus, the inclusion of new ingredients in diets that maintain performance and keep costs down was welcomed by rabbit producers.

Many countries in West and central of Africa and others in the tropical regions of South America and Asia used Panicum maximum $(\mathrm{Pm})$ as forage for animals. That plant is related to the Poaceae family. It has many common names like Guinea grass, buffalo grass, and zacate Guinea. This grass was traditionally used in these aeries as a fiber source in the diet of growing rabbits (Liu et al., 2018). It is also a promising feed resource because of its various advantages such as high quality, which contains 10.5\% Crude Protein (CP), 2.5\% Ether Extract (EE), 30.4\% Crude Fiber (CF), and 7.5\% ash as reported by Ironkwe and Ukanwoko (2016). Also, it has a fast-growing rate, easy adaptation to the environment. However, only few researches have been done on the application as feed for livestock. In this respect, Udeh et al. (2007) observed that rabbits fed Pm recorded the highest feed intake compared to other forages as Centrosema pubescens and Sidaacuta. In addition, Amata and Okorodudu (2016), found that rabbits fed concentrate diet plus Pm (1:2) had higher weight gain values than rabbits fed diets concentrate diet with Myrianthus arboreus or concentrate with Gmelina arborea. Moreover, Ezea et al. (2014) concluded that pregnant rabbit fed concentrate plus a mix of forage (containing $\mathrm{Pm}$ ) recorded better weight gain of pregnant rabbits and their litters compared to the control group (fed commercial diet). Uzegbu et al. (2010) found that pigs that fed 5\% fresh green Pm had better final body weight than the control group and other pigs that fed 10, 15, or $20 \%$ fresh green Pm.

The current study aimed to evaluate the effect of inclusion Pm instead of clover hay to the diet on the growth performance of growing rabbits.

\section{MATERIALS AND METHODS}

\section{Location of the study}

The experimental work was carried out at the El-Serw Research Farm, in the Dametta governorate in Northern Egypt, Animal Production Research Institute, Ministry of Agriculture. 


\section{Ethical approval}

The protocol for the present study was carried out at the meeting of the Animal Production Research Institute Scientific and Ethics Committee (Protocol No. 02-03-03-429).

\section{Preparation of Panicum maximum}

The grass was chopped to a length of 90 centimeter $(\mathrm{cm})$ (about 1month old) and air-dried inside an empty room on the farm, turned over in the morning and evening then packed with Pm hay until the start of the experiment.

\section{Experimental design}

Two experiments were conducted in the present study. In the first experiment, six adult V-line male rabbits were used in the farm where we did the experimental work to determine Digestible Energy (DE) by feeding each rabbit with 240 gram $(\mathrm{g})$ (120 g clover hay $+120 \mathrm{~g} \mathrm{Pm}$ ) for seven days was divided into 4 days for adjustment, followed by further 3 days for data collection, where the feed intake was calculated and the feces were collected. Then feces dried and analyzed for gross energy according to the official methods (AOAC, 2000). In the second experiment, a total number of $64 \mathrm{~V}$-line rabbits at the age of 6 weeks, with an average weight of $702 \mathrm{~g} \pm 6$ were divided equally into 4 groups in 4 replicates, each with 4 rabbits ( 8 male and 8 female) existed for each group. Control group was fed a basal diet (T1), while the others three groups were fed graded Pm levels of 15\%, 30\%, and 45\% to replace the percentage of clover hay to $4.5 \%, 9 \%$, and $13.5 \%$ of the whole diet, which represents T2, T3, and T4, respectively. Experimental diets in pellet form and water were offered ad-libitum during the 8-weeks growth period. The composition and calculated analysis of the tested diets were listed in table 1 and covered the requirement of growing rabbit (Agriculture Ministry Decree, 1996). All diets contained almost $17 \%$ CP with $2500 \mathrm{kcal} \mathrm{DE}$; DE/kg. Rabbits were housed in wire batteries with an open and good ventilation system. Meanwhile, live weight and feed intake were recorded, body weight gain and feed conversion ratio were calculated.

Table 1. Feed ingredients and calculated analysis of the experimental diets

\begin{tabular}{|c|c|c|c|c|}
\hline Ingredients (Percentage) & T1 & $\mathbf{T 2}$ & T3 & T4 \\
\hline Clover hay (12\%) & 30 & 25.50 & 21.00 & 16.50 \\
\hline Panicum maximum & --- & 4.50 & 9.00 & 13.5 \\
\hline Yellow corn & 22.03 & 22.03 & 22.03 & 22.03 \\
\hline Wheat bran & 22.17 & 22.17 & 22.17 & 22.17 \\
\hline Soybean meal (44\%) & 19.30 & 19.30 & 19.30 & 19.30 \\
\hline Molasses & 3.00 & 3.00 & 3.00 & 3.00 \\
\hline Di calcium phosphate & 2.27 & 2.27 & 2.27 & 2.27 \\
\hline Salt & 0.50 & 0.50 & 0.50 & 0.50 \\
\hline Vitamin \& mineral mix $*$ & 0.30 & 0.30 & 0.30 & 0.30 \\
\hline Limestone & 0.24 & 0.24 & 0.24 & 0.24 \\
\hline D.L. Methionine & 0.14 & 0.14 & 0.14 & 0.14 \\
\hline Anticoccidia (Diclazuril) & 0.05 & 0.05 & 0.05 & 0.05 \\
\hline Total & 100 & 100 & 100 & 100 \\
\hline \multicolumn{5}{|l|}{ Calculate analysis } \\
\hline Crude protein $(\%)$ & 17.19 & 17.18 & 17.16 & 17.14 \\
\hline Digestible energy (Kcal/kg) & 2530 & 2538 & 2546 & 2554 \\
\hline Crude fiber $(\%)$ & 13.35 & 13.38 & 13.41 & 13.44 \\
\hline Crude fat $(\%)$ & 2.64 & 2.67 & 2.70 & 2.70 \\
\hline Calcium $(\%)$ & 1.14 & 1.10 & 1.05 & 1.01 \\
\hline Total phosphorus (\%) & 0.86 & 0.86 & 0.85 & 0.85 \\
\hline Lysine (\%) & 0.92 & 0.92 & 0.92 & 0.92 \\
\hline Methionine + cyctein $(\%)$ & 0.70 & 0.69 & 0.67 & 0.66 \\
\hline
\end{tabular}

*Each 3 kg contain: 6000000 IU Vitamine A; 900000 IU Vitamin D3; 40000 mg Vitamin E; 2000 mg Vitamin K3; 2000 mg Vitamin B1; 4000 mg Vitamin B2; $2000 \mathrm{mg}$ Vitamin B6; $10 \mathrm{mg}$ Vitamin B12; $50 \mathrm{mg}$ Biotin; $10000 \mathrm{mg}$ Pantothenic acid; $50000 \mathrm{Niacin} ; 3000 \mathrm{mg}$ Folic acid; $250000 \mathrm{mg}$ Choline; 8500 mg Mn; 50000 mg Zn; 50000 mg Fe; 200 mg I; 100 mg Se, 5000 mg Cu, and 100 mg Co. T1: control diet, T2: 15\% Panicum maximum, T3: 30\% Panicum maximum, T4: 45\% Panicum maximum

\section{Digestible trail}

At the end of the experimental period, a digestibility trial was conducted by using 5 rabbits / treatment to determine the digestibility coefficient of the nutrients (Dry Matter (DM), Organic Matter (OM), CP, CF, EE, and Nitrogen Free Extract (NFE)) and nutritive value of DE, Total Digestible Nutrients (TDN), and Digestible Crude Protein (DCP) according to Fekete (1985). Feed and dried feces were analyzed according to AOAC (2000). 


\section{Carcass characteristics and blood sampling}

At the end of the experimental period, five animals randomly were removed from each group and slaughtered to study carcass characteristics. Head, foreparts, hind parts, trunk, cecum, total edible parts (heart, kidneys, and liver), abdominal fat and Gastrointestinal Tract (GIT) were weighed and carcass percentage was calculated according to Cheeke (1987). Blood samples were taken from the previous animals during slaughter in heparinized test tubes to determine Hemoglobin ( $\mathrm{Hb}, \mathrm{g} / \mathrm{dl})$, Hematocrit $(\mathrm{Ht} \%)$, and Red Blood Cells (RBCs, $\left.10^{6} / \mathrm{mm} 3\right)$. The parameters which calculated are Mean Corpuscular Volume $(\mathrm{MCV})=\mathrm{Ht} \times 10 / \mathrm{RBC}$ 's $(\mu \mathrm{m} 3)$, Mean Corpuscular Hemoglobin $(\mathrm{MCH})=\mathrm{Hb} \times 10 /$ RBC's (Pg), and Mean Corpuscular Hemoglobin Concentration $(\mathrm{MCHC})=\mathrm{Hb} \times 100 / \mathrm{Ht}(\mathrm{g} / \mathrm{dl})$. White Blood Cells $\left(\mathrm{WBCs} \times 10^{3} / \mu \mathrm{l}\right)$ and its differentiation (neutrophil, eosinophil, lymphocyte, and monocyte). All measurements performed according to Clark et al. (2009).

\section{Bacterial count}

To determine the total bacterial count and coliform bacteria were collected in digesta from 12 rabbits ( 3 rabbits per treatment) and used for microbial assays using the spread plate technique described by Quinn et al. (1994). The microbial level was expressed as a Colony-Forming Unit (CFU) per gram of sample. The different isolated bacterial colonies were further identified according to Holt et al. (1994).

\section{Tissues Specimens}

Tissues specimens were taken during the dressing process, with the proper tissue samples obtained from the liver for histo-pathological examination. The tissues were immediately fixed in a $10 \%$ formalin-saline solution. Dried samples were cleaned in 70\% absolute alcohol. All samples were then dehydrated in ascending strengths of $70 \%$ absolute alcohol. After clearing in xylol, infiltration, and embedding in paraffin wax, the tissue block was sectioned and then stained by hematoxyl in and eosin stains, according to Mescher (2016). The histological sections (4 to 5 microns) were examined with a light microscope supplied with an electric lamp, and the magnification power was 400X.

\section{Statistical analysis}

The data collected was analyzed statistically by the analysis of variance using the SAS Institute's General Linear Model (GLM) (SAS, 2004). Significant differences between treatments were performed using the Duncan's multiple range test (Duncan, 1955). The model used in the current experiment was $Y_{i j}=\mu+T_{i}+e_{i j} \cdot \mu=$ overall mean of $Y_{i j}, T=$ effect of treatment, $\mathrm{i}=(1,2,3$ and 4$)$, and $\mathrm{e}_{\mathrm{ij}}=$ experimental error.

\section{RESULTS}

The proximate composition analysis, the amino acid profile and the tannin content of Pm are given in table 2. Pm contains nearby similar CP to clover hay (11.65\% and $12 \%), \mathrm{CF}(30.66 \%$ and $30 \%)$, crude fat $(2.76 \%$ and $2.1 \%)$ and $\mathrm{DE}$ (1959 and 1780) which indicate that Pm is suitable to replace clover hay in rabbit nutrition.

\section{First experiment}

According to the analysis by AOAC (2000), the DE of Pm was $1959 \mathrm{kcal} / \mathrm{kg}$, and knowing its DE, all diets were formulated and then used in the second experiment.

\section{Second experiment}

The effect of different Pm levels on the growth performance of growing rabbits is presented in table 3 . The rabbits fed higher Pm level recorded significantly the best final weight compared to the control and T3 groups, but without a significant difference from T2. The same trend was observed with daily weight gain. Although feed intake was not significantly influenced by the treatments examined, it is noticeable that all groups that received different Pm levels recorded higher Feed Intake (FI) value rather than control, which indicates that the increase the inclusion of Pm in the feed the palatability of the food increased.

In terms of feed conversion ratio, a group of $\mathrm{T} 4$ recorded the best FCR without significant differences from the T2 group, but with significant differences from the control and a group of T3. As shown in table 4, the digestibility of CP was significantly enhanced in control group, $\mathrm{T} 2$ and $\mathrm{T} 4$, while the group of $\mathrm{T} 3$ recorded the lowest value. However, control groups and T4 achieved a significantly higher CF digestibility than T2 and T3 groups. The rest of nutrient digestibility (DM, OM, EE and NFE) did not significantly affected via different groups. In respect of nutritional values, only the DCP was significantly affected, which followed the same trend of CP digestibility. On the other hand, TDN and DE had no significant effects from different treatments. The carcass characteristics of rabbits fed graded Pm inclusion levels (table 5) did not affect by the treatments, with the exception of the carcass and foreparts percentage, where the T2 and T3 groups recorded significantly higher carcass percentage values than the control group, while foreparts percentage was significantly improved in T3 compared to control and T4 groups, but insignificantly in T2. 
The effect of different levels of Pm inclusion on the serum hematological parameters is listed in table 6. Rabbits fed T3 diet recorded a significantly higher RBC's count of $13.1 \%$ compared to the control group, $16.4 \%$, and $19.8 \%$ compared to T2 and T4, respectively. On the other hand, $\mathrm{Ht} \%, \mathrm{Hb}, \mathrm{MCV}, \mathrm{MCH}$ and MCHC values had no significant influence on the treatments studied. White blood cells and their fractions were almost significantly affected by the inclusion of Pm in growing rabbit's diet. It is clear that rabbits fed T4 diet recorded fewer WBC count and neutrophil cells compared to other treatments. In addition, both groups of T2 and T4 recorded significantly higher lymphocyte counts of $17.6 \%$ and $31.8 \%$, respectively, compared to the control group. The group of T2 recorded significantly the worst value of eosinophil. However, none of the treatments indicated an improvement in the monocyte count.

As shown in table 7, all of the groups tested had a higher total bacterial count in the cecum than the control group. Increasing the dietary Pm level, was significantly decreased the total bacterial count. Rabbits fed T3 recorded a significantly higher total coliform bacteria count, followed by the control group, then the T4 group and finally the lowest count was recorded for the $\mathrm{T} 2$ group.

According to the histological assessment, plates 1 to 4 showed liver histological sections of different treatments. The liver of control group showed degeneration in hepatocytes, focal area of hepatocellular necrosis, and edema in the sinusoids (Figure 1a). In the second group (T2), the central vein showing dilatation, dilated sinusoids and degeneration in hepatocytes (Figure 1b). In the third group (T3), the portal area showed dilated portal blood vessel, newly formed bile ductules, the focal area of hepatocellular necrosis and the hepatocyte, which revealed degeneration (Figure 1c). While in the fourth group (T4), there was granular degeneration of the hepatocytes, focal area of the hepatocellular necrosis and dilated hepatic sinusoids (Figure 1d).

Table 2. Chemical composition and amino acids profile of Panicum maximum

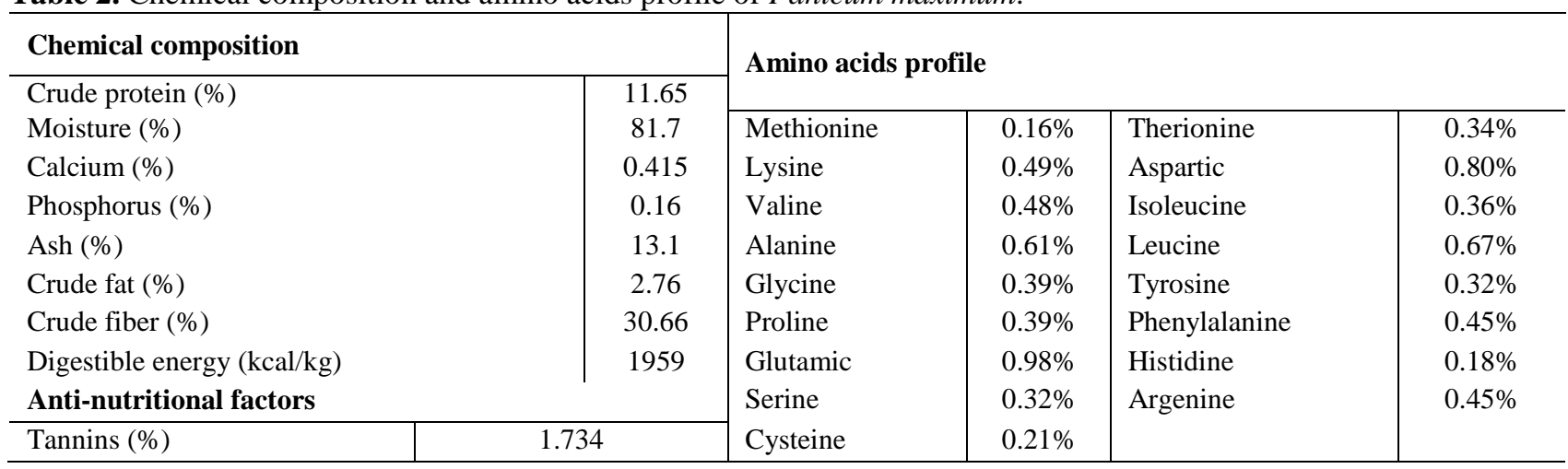

Table 3. Effect of inclusion of Panicum maximum on growth performance of growing rabbits.

\begin{tabular}{lccccc}
\hline Characteristics & T1 & T2 & T3 & T4 & SEM \\
\hline Initial weight $(\mathrm{g})$ & 709 & 712 & 713 & 702 & 6.25 \\
Final weight $(\mathrm{g})$ & $1736^{\mathrm{b}}$ & $1848^{\mathrm{ab}}$ & $1744^{\mathrm{b}}$ & $1988^{\mathrm{a}}$ & 50.8 \\
Daily weight gain (g) & $18.3^{\mathrm{b}}$ & $20.3^{\mathrm{ab}}$ & $18.4^{\mathrm{b}}$ & $23.0^{\mathrm{a}}$ & 0.91 \\
Total feed intake (g) & 5017 & 5175 & 5293 & 5131 & 75.4 \\
FCR (g feed/g gain) & $4.99^{\mathrm{a}}$ & $4.59^{\mathrm{ab}}$ & $4.96^{\mathrm{a}}$ & $3.82^{\mathrm{b}}$ & 0.22
\end{tabular}

$\overline{\mathrm{a}, \mathrm{b}}$ : Means in the same row with different superscripts are significantly different $(\mathrm{p} \leq 0.05)$. T1: control diet, T2: 15\% Panicum maximum, T3: 30\% Panicum maximum, T4: 45\% Panicum maximum

Table 4. Effect of inclusion of Panicum Maximum on digestion coefficients and nutritive values of growing rabbits.

\begin{tabular}{|c|c|c|c|c|c|}
\hline Nutrients & T1 & $\mathbf{T 2}$ & T3 & T4 & SEM \\
\hline \multicolumn{6}{|l|}{ Digestion coefficient (\%) } \\
\hline Dry matter & 69.24 & 65.48 & 66.61 & 66.84 & 2.53 \\
\hline Organic matter & 71.19 & 67.88 & 69.23 & 65.73 & 2.51 \\
\hline Crude protein & $74.23^{\mathrm{a}}$ & $73.18^{\mathrm{a}}$ & $68.46^{\mathrm{b}}$ & $72.40^{\mathrm{a}}$ & 1.01 \\
\hline Crude fiber & $42.70^{\mathrm{A}}$ & $31.30^{\mathrm{B}}$ & $34.22^{\mathrm{B}}$ & $42.26^{\mathrm{A}}$ & 1.54 \\
\hline Ether extract & 79.15 & 76.20 & 77.08 & 76.84 & 1.69 \\
\hline Nitrogen free extract & 76.39 & 74.26 & 70.21 & 72.83 & 4.18 \\
\hline \multicolumn{6}{|l|}{ Nutritive values } \\
\hline Total digestible nutrients (TDN) & 66.52 & 63.53 & 64.43 & 61.90 & 2.69 \\
\hline Digestible crude protein (DCP) & $12.62^{\mathrm{a}}$ & $12.44^{\mathrm{a}}$ & $11.64^{\mathrm{b}}$ & $12.31^{\mathrm{a}}$ & 0.172 \\
\hline Digestible energy; $\mathrm{kcal} / \mathrm{kg}(\mathrm{DE})^{*}$ & 2946 & 2814 & 2854 & 2742 & 119.47 \\
\hline
\end{tabular}


Table 5. Effect of inclusion of Panicum maximum on carcass characteristics of growing rabbits.

\begin{tabular}{lccccc}
\hline Items (\%) & T1 & T2 & T3 & T4 & SEM \\
\hline Carcass & $61.88^{\mathrm{c}}$ & $65.4^{\mathrm{a}}$ & $65.2^{\mathrm{ab}}$ & $62.6^{\mathrm{bc}}$ & 0.685 \\
Head & 4.98 & 5.23 & 5.74 & 5.19 & 0.236 \\
Fore parts & $19.04^{\mathrm{bc}}$ & $19.46^{\mathrm{ab}}$ & $20.17^{\mathrm{a}}$ & $18.32^{\mathrm{c}}$ & 0.267 \\
Hind parts & 20.64 & 21.73 & 22.61 & 23.42 & 1.423 \\
Trunk & 13.22 & 13.46 & 13.31 & 13.54 & 0.369 \\
Cecum & 5.09 & 5.01 & 4.70 & 5.21 & 0.549 \\
Total edible parts & 3.84 & 3.74 & 3.55 & 3.69 & 0.316 \\
Abdominal fat & 0.77 & 0.77 & 0.67 & 0.68 & 0.042 \\
GIT* & 15.07 & 12.27 & 14.84 & 14.72 & 0.72 \\
\hline a, b, c: Means in the same row with different superscripts are significantly different. (p $\leq 0.05)$ * ${ }^{*}$ GIT: gastrointestinal tract, T1: control diet, T2: 15\% \\
Panicum maximum, T3: 30\% Panicum maximum, T4: 45\% Panicum maximum & & & &
\end{tabular}

Table 6. Effect of inclusion Panicum maximum on serum hematological parameters of growing rabbits.

\begin{tabular}{lccccc}
\hline Parameters & T1 & T2 & T3 & T4 & SEM \\
\hline RBC $\left(10^{6} / \mathrm{mm}^{3}\right)$ & $5.34^{\mathrm{B}}$ & $5.19^{\mathrm{B}}$ & $6.04^{\mathrm{A}}$ & $5.04^{\mathrm{B}}$ & 0.154 \\
$\mathrm{Ht}(\%)$ & 32.95 & 31.3 & 34.55 & 32.05 & 1.263 \\
$\mathrm{Hb}(\mathrm{g} / \mathrm{dl})$ & 11.1 & 10.85 & 11.7 & 10.55 & 0.545 \\
$\mathrm{MCV}(\mu \mathrm{m} 3)$ & 61.7 & 60.3 & 57.35 & 63.5 & 1.503 \\
$\mathrm{MCH}(\mathrm{Pg})$ & 20.75 & 20.9 & 19.5 & 20.8 & 0.744 \\
$\mathrm{MCHC}(\mathrm{g} / \mathrm{dl})$ & 33.65 & 34.75 & 34.0 & 32.7 & 0.514 \\
$\mathrm{WBC}\left(\times 10^{3} / \mu \mathrm{l}\right)$ & $9.3^{\mathrm{a}}$ & $10.4^{\mathrm{a}}$ & $10.1^{\mathrm{a}}$ & $6.65^{\mathrm{b}}$ & 0.737 \\
Neutrophile $(\%)$ & $49.5^{\mathrm{A}}$ & $43.5^{\mathrm{A}}$ & $44.0^{\mathrm{A}}$ & $34.0^{\mathrm{B}}$ & 1.968 \\
Lymphocyte $(\%)$ & $42.5^{\mathrm{C}}$ & $50.0^{\mathrm{AB}}$ & $48.0^{\mathrm{BC}}$ & $56.0^{\mathrm{A}}$ & 1.854 \\
Monocyte $(\%)$ & 6.0 & 5.5 & 6.0 & 8.0 & 1.25 \\
Esinophile $(\%)$ & $2.0^{\mathrm{A}}$ & $1.0^{\mathrm{B}}$ & $2.0^{\mathrm{A}}$ & $2.0^{\mathrm{A}}$ & 0.001 \\
\hline
\end{tabular}

$\overline{\mathrm{A}, \mathrm{B}, \mathrm{C}}$ : Mean in the same row with different superscripts are significantly different. $(\mathrm{p} \leq 0.05){ }^{\mathrm{A}}$ and ${ }^{\mathrm{B}}$ Means in the same row with different superscripts are significantly different $(\mathrm{p} \leq 0.01)$. Mean Corpuscular Volume $(\mathrm{MCV})=\mathrm{Ht} \times 10 / \mathrm{RBC}$ 's $(\mu \mathrm{m} 3)$, Mean Corpuscular Hemoglobin $(\mathrm{MCH})=\mathrm{Hb} \times 10 /$ RBC's (Pg) Mean Corpuscular Hemoglobin Concentration $(\mathrm{MCHC})=\mathrm{Hb} \times 100 / \mathrm{Ht}(\mathrm{g} / \mathrm{dl})$. T1: control diet, T2: 15\% Panicum maximum, T3: 30\% Panicum maximum, T4: 45\% Panicum maximum

Table 7. Effect of inclusion Panicum Maximum on cecum bacterial count in growing rabbits.

\begin{tabular}{lccccc}
\hline Bacterial count & T1 & T2 & T3 & T4 & SEM \\
\hline Total bacterial count & $7.11 \times 10^{10 \mathrm{C}}$ & $5.3 \times 10^{12 \mathrm{~A}}$ & $3.0 \times 10^{12 \mathrm{~B}}$ & $8.86 \times 10^{10 \mathrm{C}}$ & 0.626 \\
Coli-form count & $2.99 \times 10^{8 \mathrm{~B}}$ & $1.26 \times 10^{6 \mathrm{D}}$ & $4.99 \times 10^{8 \mathrm{~A}}$ & $7.47 \times 10^{6 \mathrm{C}}$ & 1.139
\end{tabular}

$\overline{\mathrm{A}, \mathrm{B}, \mathrm{C}, \mathrm{D}}$ : Means in the same row with different superscripts are significantly different ( $\mathrm{p} \leq 0.01)$. T1: control diet, T2: 15\% Panicum maximum, T3: $30 \%$ Panicum maximum, T4: 45\% Panicum maximum

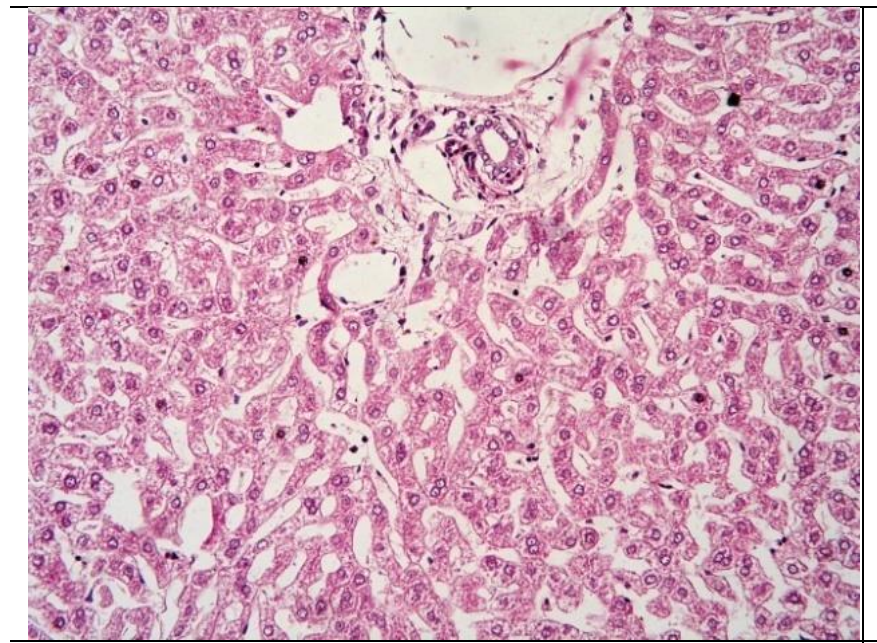

a. Degeneration in the rabbits' hepatocytes, focal area of hepatocellular necrosis, and edema in the sinusoids in the Control group.

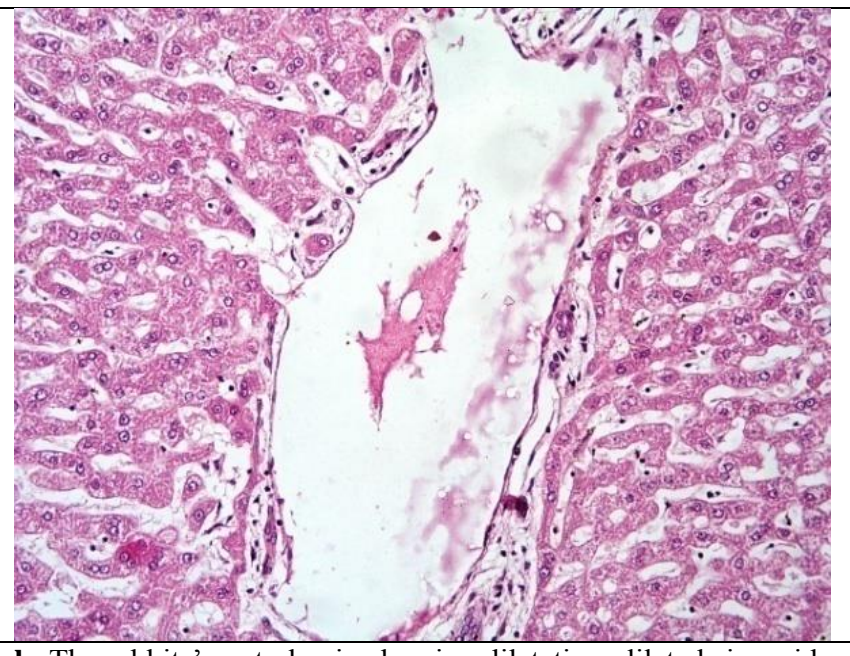

b. The rabbits' central vein showing dilatation, dilated sinusoids and degeneration in hepatocytes in $\mathrm{T} 2$ (fed $15 \%$ Panicum maximum) 


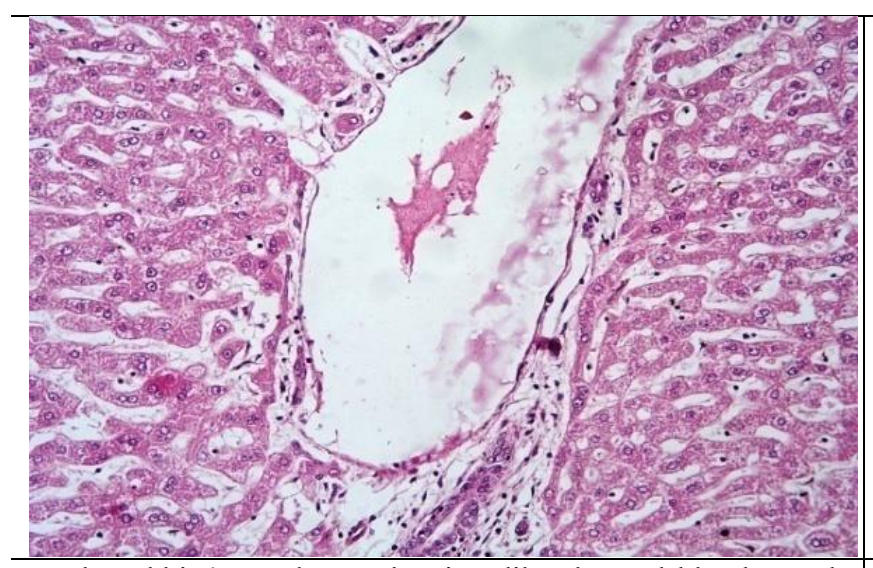

c. The rabbits' portal area showing dilated portal blood vessel, newly formed bile ductules, focal area of hepatocellular necrosis and the hepatocyte revealing degeneration in T3 (fed 30\% Panicum maximum)

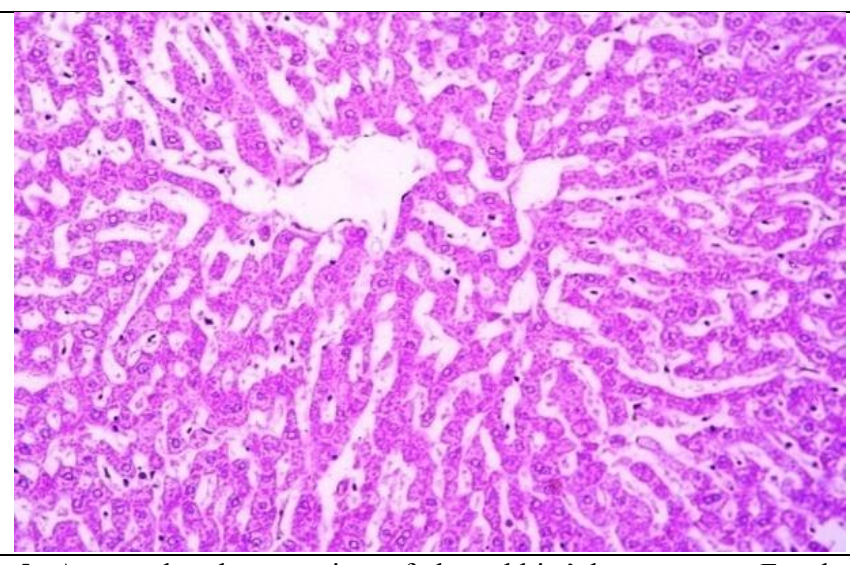

d. A granular degeneration of the rabbits' hepatocytes. Focal area of hepatocellular necrosis and dilated hepatic sinusoids in T4 (fed $45 \%$ Panicum maximum).

Figure 1. Liver histology of growing rabbits fed different inclusion levels of Panicum maximum

\section{DISCUSSION}

Rabbits fed T4 recorded 14.5\% significantly higher final weight compared to the control group. This enhancement may be due to better quality of mixing Pm hay (grass hay) with legume hay (clover hay) than only the clover hay (control diet) as documented by Ezenwa and Aken'Ova (1998). In this respect, Uzegbu et al. (2010) concluded that the inclusion of pig diet by $5 \%$ fresh green guinea grass $(\mathrm{Pm})$ increased the final weight and weight gain. An earlier study on feeding lambs with a diet contained guinea grass with coconut or fishmeal, reported a better growth performance (Hammond and Wildeus, 1991). Also, Ajayi et al. (2008) documented that feeding goats with Pm with Lablab purpureus gave the highest performance as presented in weight gain. Recently, Salama and Abo El-Azayem (2018) found that replacing clover hay with either $25 \%$ or $50 \%$ of the biologically treated discarded palm fronds resulted in $13.8 \%$ and $10.1 \%$ improvements in final weight compared to control group. Moreover, Abd- El Ghany et al. (2016) documented that rabbits fed diets containing conocarpus treated with bacteria and fungi had significantly $(\mathrm{p} \leq 0.05)$ higher live body and daily weight gain than those fed with the other experimental diets. On the contrary, Ifeanyichukwu et al. (2007) studied the effects of inclusion in different forages (Pm, Centrosema pubescens and Sida acuta) on the growth performance of rabbit. They concluded that there was no significant variation in weight gain between all groups. It is known that fiber content affects the performance of growing rabbits, depending on the fiber source (lignification, cell wall complexity, and different hemicellulose), as reported by García et al. (2002).

In the present study, higher feed intake of rabbits in all groups fed with Pm may be due to the higher palatability of the diets. This finding was confirmed by Ifeanyichukwu et al. (2007), who reported that Pm-fed rabbits indicated the highest feed intake, followed by those fed with $C$. pubsecens, and $S$. acuta compared to the control group. Phimphachanhvongsod and Ledin (2002) also had found that feeding growing goats with guinea grass recorded a significantly higher feed intake than others fed with Gliricidia sepium leaves. In addition, the improvement in FCR in the 45\% Pm T4 group was $23.4 \%$ compared to the control group. This decreased in FCR indicated professional feed consumers, which confirmed the findings of Bamikole and Ezenwa (1999), who reported that feeding rabbits with forge (Pm) with concentrate achieved better FCR than others were fed only by forage. Moreover, Uzegbu et al. (2010) documented that feeding pig with 5\% fresh Pm achieved lower feed intake with better FCR by $20.2 \%$ compared to the untreated group. The enhancement in growth performance may be due to insignificant differences in CP and CF between T4 and the control group. These results were in agreement with Ajayi et al. (2008), who concluded that goats fed Pm with Lablab purpureus had higher values of nitrogen digestibility and utilization than goats fed either Stylosanthesguianensis, Lablab purpureus, Aeschynomenehistrix, or Centrosema pubescens. On the other hand, Bamikole and Babayemi (2004) demonstrated that the CP digestibility did not affect goats fed guinea grass compared to the untreated group. In addition, Salama et al. (2016) concluded that there were no significant differences in dry matter, $\mathrm{OM}, \mathrm{CP}$, and $\mathrm{CF}$ between rabbit feed with olive cake (as a substitute for clover hay) and others fed with the control diet. In the current study, the percentages of carcass and foreparts in groups of T2 and T3 indicated a significantly higher percentages than in control group, which agrees with Salama et al. (2016), who reported that replacing clover hay in rabbit diets by diets containing $30 \%$ olive cake with $1 \%$ bentonite resulted in insignificant variations in the carcass. AbdEl Ghany et al. (2016) concluded that rabbits fed $15 \%$ and $30 \%$ conocarpus and treated with fungi to replace clover hay achieved the highest carcass weight. In the present study, although the RBC's values were in the normal range, it was observed that the RBC values were significantly decreased in the control, T2 and T4 groups in comparison to T3 group and this may be due to the presence of tannins in Pm, which is considered as an anti-nutritional factor. The same 
conclusion was made by Yusuf et al. (2012), who found that RBC's were lower in goats fed 25\% Pm/ 75\% NL compared to the control group. It is known that hematological parameters (RBC's and WBC's) are usually related to health status and are of diagnostic importance for the clinical evaluation of the health state. Moreover, any change in the hematological status of the animals explains the impacts of the nutrients and ration ingredients used, while, these parameters were within the normal range and indicate that the animals have a good physiological, pathological and nutritional status. Therefore, any changes in hematological parameters could be used to clarify the influence of nutritional factors and ingredients in the diet on living creature (Ganong, 1999). Due to the increased WBC's count and their fractions in the control group, may the poor growth performance in this group could be explained, which the most of nutrients were forwarded to the synthesize and development of immune organs, hence reduced the number of nutrients available for growth as reported previously by Tajodini et al. (2014). White Blood Cells are known to be the body's first lines of defense (Ganong, 1999). The highest number of cecum harmful bacteria in the group of T3 could explain the lowest growth performance in the present study, although T2 and T4 achieved the lowest number of coliform bacteria. The results confirmed the previous findings of Abd- El Ghany et al. (2016), who reported that the total bacteria count in rabbits fed either $15 \%$ or $30 \%$ conocarpus treated with Trichoderma reesi (partial replacement of clover hay), was significantly higher than control rabbits. Lelkes (1987) concluded that increasing cellulose in food increased the number of cellulomonace bacteria, which improved cellulose digestion.

\section{CONCLUSION}

Panicum maximum can replace up to $45 \%$ of the clover hay in the growing rabbit's diet, which caused higher growth performance than the control group by improving the digestibility of $\mathrm{CP}, \mathrm{CF}$ and decreasing the coliform bacteria count.

\section{DECLARATIONS}

\section{Authors' contribution}

Dr. Amira M Refaie collaborated with the idea of this research and wrote the manuscript. Dr. Walaa A Salama worked on the main idea and design of the experiment. Dr. Ahmed E. Shams Eldeen performed the experimental chemical and statistical analyses. Dr. Malak M. Boshra and Dr. Ahmed Alazab carried out the practical part of the experiment, and Dr. Fouad S Khalil tabulated the experimental data and offered the grass used in this research.

\section{Competing interests}

The authors have declared that there is no competing interest.

\section{REFERENCES}

AOAC (2000). Official Methods of Analysis. $17^{\text {th }}$ edition, published by the A.O.A.C., Washington, D.C., USA. Available at: https://www.sigmaaldrich.com/catalog/product/aldrich/z423645?lang=en\&region=EG

Abd- El Ghany FTF, Ali W AH, Mahmoud MA, and Abdel-Mawla LF (2016). Effect of partial replacement of berseem hay by biologicaly treated conocarpus on productive performance and physiological response of growing rabbits..Proceedings of the $9^{\text {th }}$ International Poultry conference of the Egyptian Poultry Association, Hurghada (Egypt), pp. 7-10. Available at: http://goo.gl/forms/IZhzqs6jTl

Agriculture Ministry Decree (1996). The standard properties for ingredients, feed additives and feed manufactured for animal and poultry. El-Wakaee El-Masria, Amirria Press Cairo, Egypt. 192: 95. Available at: https://www.ecolex.org/details/legislation/decree-no-22-of-1996-of-the-ministry-ofagriculture-on-veterinary-products-lex-faoc012988/

Ajayi O, Jacob BMI and Taiwo AA (2008). Effects of supplementation of Panicum maximum with four herbaceous forage legumes on performance, nutrient digestibility and nitrogen balance in West African dwarf goats. Animal Science Journal, 79 : 673-679. DOI:https://doi.org/10.1111/j.1740-0929.2008.00579.x

Amata IA, and Okorodudu EO (2016). Comparative evaluation of the growth performance and feed intake of weaned rabbits fed tropical grasses and selected forage leaves. International Journal of Research Studies in Agricultural Sciences, 2: 14-18. DOI: http://dx.doi.org/10.20431/24556224.0202003

Bamikole, MA and Babayemi OJ (2004). Feeding goats with guinea grass - verano stylo and nitrogen fertilized grass with energy concentrate. Archivosde. Zootecnia, 53: 13-23. Available at: https://www.semanticscholar.org/paper/Feeding-goats-with-Guinea-grass-Verano-stylo-andBamikole-Babayemi/686ace88f9030f334195735b6db8d9d8b061f385

Bamikole MA and Ezenwa I (1999). Performance of rabbits on Guinea grass and Verano stylo hays in the dry season and effect of concentrate supplementation. Animal Feed Science and Technology, 80: 67-74. Available at: http://agris.fao.org/agrissearch/search.do?recordID=NL2000000182 Cheeke PR (Editor) (1987). Rabbit feeding and Nutrition. Academic Press, San Diego (USA). Available at: https://www.sciencedirect.com/book/9780121706050/rabbit-feeding-and-nutrition

Clark P, Boardman W and Raidal S (2009). Atlas of clinical avian hematology. Wiley-Blackwell (editor), Australia. pp. 100-120. Available at: https://www.academia.edu/18199421/Atlas_of_Clinical_Avian_Hematology__Philip_Clark_Wayne_Boardman_and_Shane_Raidal

Duncan DB (1955). Multiple range and multiple F tests. Biometrics, 11: 1-42.Available at: https://www.jstor.org/stable/pdf/3001478.pdf?seq=1

Ezea J, Iwuji TC and Oguike MA (2014). Growth response of pregnant rabbits and their litters fed spreading day flower (Commelina diffusa burm F.) and rock fig (Ficus ingens miquel) leaves. Journal of Global Bioscience 3(2): 619-625. Available at: http://mutagens.co.

Ezenwa I and Aken'Ova ME (1998). Performance of mixtures of selected grasses and adapted herbaceous legumes in southwest Nigeria. Tropical Grassl,

32: 131-138. Available 
http://www.tropicalgrasslands.info/public/journals/4/Historic/Tropical\%20Grasslands\%20Journal\%20archive/Abstracts/Vol_32_1998/Abs_32_0 2_98_pp131_138.html

Fekete S (1985). Rabbit feeds and feeding with special regard to tropical condition. Journal of Applied Rabbit Research, 8: 167-173. Available at: https://www.feedipedia.org/node/21927

Ganong WF (1999). Review of medical physiology. $19^{\text {th }}$ edition. Stanford, Connecticut, Appleton and Lange, p. 353. Available at: https://scholar.google.com.eg/scholar?q=Review+of+medical+physiology\&hl=ar\&as sdt=0\&as vis=1\&oi=scholart

García J, Nicodemus N, Carabaño R, and De Blas C (2002). Effect of inclusion of deffated grape seed meal in the diet on digestion and performance of growing rabbits. Journal of Animal Science, 80: 162-170. DOI: https://doi.org/10.2527/2002.801162x

Hammond AC, and Wildeus S (1991). Protein supplements for hair sheep fed a tropical grass based diet. S. Wildeus (Editor), Proceedings of Hair Sheep Research Symposium, St. Croix, Virgin Islands, United States, pp. 228-235. Available at: https://www.uvi.edu/research/agriculturalexperiment-station/animal-science/animal-science-hair-sheep/animal-science-hair-sheep-research.aspx

Holt JC, Krieg NR, Sneath PHA, Staley JT, and William ST (1994). Bergeys manual of determination bacteriology, 9th edition, Williams and Wilkins. Baltimore. Available at: https://www.scirp.org/(S(lz5mqp453edsnp55rrgjct55))/reference/ReferencesPapers.aspx?ReferenceID=1838672

Ifeanyichukwu U, Okorie EO, and Evylene A (2007). Performance of weaner rabbits fed panicum maximum, centrosema pubescens and sida acuta supplemented with poultry growers mash. Animal Research International, 4(3): 750-752. Available at: https://pdfs.semanticscholar.org/fa38/6c41d3a7a82f3b77e8d82168990742b0a1f3.pdf

Ironkwe MO and Ukanwoko AI (2016). The evaluation of concentrate and forage combination on the performance of litter weight of New Zealand rabbit. Greener Journal of Agriculture Science, 6(10): 312-315. Available at: DOI: $\underline{10.15580 / G J A S .2016 .10 .102616172}$

Lelkes L (1987). A review of rabbit enteric disease: a new perspective Journal of Applied Rabbit Research, 10: 55-61. DOI or Available at:Available at: https://www.scopus.com/record/display.uri?eid=2-s2.0-0042103300\&origin=inward\&txGid=2a25f9218f3a7d85f1398a49fee48fcd

Liu GY, Sun CR, Zhao XY, Liu HL, Wu ZY and Li FC (2018). Effect of substituting guinea grass with sunflower hulls on production performance and digestion traits in fattening rabbits. World Rabbit Science, 26: 217-225. Available at: https://www.semanticscholar.org/paper/EFFECT-OFSUBSTITUTING-GUINEA-GRASS-WITH-SUNFLOWER-LIUG./7f2bda83035daea4e7bba4e4e18c3487431363c3

Mescher AL (2016). Junqueira's Basic Histology Text \& Atlas (14th edition), the McGraw-Hill companies Incorporated. Indiana (USA). Available at: https://www.academia.edu/37006818/Junqueiras_Basic_Histology_Text_and_Atlas_14th_Edition

Phimphachanhvongsod V, and Ledin I (2002). Performance of Growing Goats Fed Panicum maximum and Leaves of Gliricidia sepium. (Asian-Aust. Journal of Animal Science, 15(11): 1585-1590. Available at: http://www.ajas.info/

Quinn PJ, Carter ME, Markey B and Carter GR (1994). Clinical Veterinary Microbiology. 2nd Edition Wolf/Mosby, London. pp. 47-60. Available at: https://www.elsevier.com/books/clinical-veterinary-microbiology/markey/978-0-7234-3237-1

Salama WA and Abo El-Azayem EH (2018). Partial replacement of clover hay by discarded palm fronds on performance of growing rabbits. Egyptian Journal of Rabbit Science, 28: 173 -193. DOI: 10.21608/EJRS.2018.46509

Salama WA, Basyony MM, Suliman MA, Matari RIM and Hassanein HAM (2016). Effect of feeding olive cake supplemented with or without bentonite on performance of growing rabbits. Egyptian Journal of Rabbit Science, 26: 211-230. DOI: 10.21608/EJRS.2016.42076.

SAS (2004). SAS/DSTAT User's Guide: Statistics, Release 6.04, SAS Institute, Incorporated, Cary, NC., USA. Available at: https://support.sas.com/en/software/sas-stat-support.html

Schneider B and Flatt W (1975). The evaluation of feeds through digestibility experiments. The University of Georgia Press; Athens. USA. pp. 161-167. Available at: https://www.ncbi.nlm.nih.gov/pmc/articles/PMC1697552/

Tajodini M, Samadi F, Hashemi SR, Hassani S and Shams-Shargh M (2014). Effect of different levels of Artichoke (Cynara scolymus L.) powder on the performance and immune response of broiler chickens. International Journal of Agricultural Science, 4: 66-73. Available at: https://www.semanticscholar.org/paper/Effect-of-different-levels-of-Artichoke-(Cynara-L.)-TajodiniSamadi/a221174a81bf47a110aea037f0ca1d63eb396ab3

Udeh I, Ekwe OO and Aaron E (2007). Performance of weaned rabbits fed panicum maximum, centrosema pubescens and sida acuta supplemented with poultry growers mash. Animal Research International, 4(3): 750-752. Available at: https://www.academia.edu/31088826/PERFORMANCE OF WEANER RABBITS FED PANICUM MAXIMUM CENTROSEMA PUBES CENS_AND_SIDA_ACUTA_SUPPLEMENTED_WITH_POULTRY_GROWERS_MASH

Uzegbu HO, N delekwute EK, Igwe IR., Ekedo TO, Ekwe CC, Ukin CI and Ebeniro NC (2010). Growth response of grower pigs feed diets containing fresh green guinea grass (panicum maximum) as forage supplement. International Journal of Current Research, 11: 174-177. Available at: http://journalcra.com/article/growth-response-grower-pigs-feed-diets-containing-fresh-green-guinea-grass-panicum-maximum

Yusuf AO, Oyebanji OA, Yusuf DA, Ekunseitan KA, Adeleye OS and Sowande FOA (2012). Blood profile of west Africandwarf goats fed panicum maximum supplemented with new bouldia laevis leaves. Bulletin of Animal Health and Production in Africa, 60: 481-490. Available at: https://www.ajol.info/index.php/bahpa/article/view/91863 